\title{
AKIBAT HUKUM PENOLAKAN PERMOHONAN ITSBAT NIKAH OLEH PENGADILAN AGAMA TERHADAP PARA PIHAK YANG MELAKUKAN NIKAH SIRI (STUDI KASUS PUTUSAN NOMOR: 1478/Pdt.G/2016/PAJT)
}

\section{HAFIDZ NUGROHO}

(Mahasiswa Program S1 Fakultas Hukum Universitas Tarumanagara)

(Email: hafidznugroho22@gmail.com)

\section{Imelda Martinelli, S.H, M.H.}

(Dosen Hukum Perdata Fakultas Hukum Universitas Tarumanagara, Meraih Sarjana Hukum Universitas Tarumangara (1990), Magister Hukum dari Fakultas Hukum Universitas

Tarumanagara (2002))

(Correspending Author)

\begin{abstract}
Siri marriage is marriage opposed to the act of mating because it is not registered, usually siri marriage used by the husband to have more than one wife, basically nikah siri do not have the force of law and not guarantee the rights of a wife and child, for that entreaty itsbat marriage to the religious court to help the parties husband and wife to get marriage certificate, so that it will have the force of law and guarantee the rights of a wife and chil, but the submission of itsbat nikah rejected by religious court by reason of the husband did not ask for permission wife in the past and the court, how did due to the law of renuncation itsbat nikah? the author examines these issues with normative juridical analysis. The data were drawn in the ruling writer analyzes that it is has no permit wife in the past and also the court, Resulting in refusal entreaty the itsbat marriage, Its impact is against marital status to be illegitimate in the state, and the status of a child to be children outside of mating. The government should supervise and socialize about the siri marriage and Due to everything that can be inflicted
\end{abstract}

Keywords: Itsbat Marriage, Siri Marriage, Marriage 


\section{Pendahuluan}

\section{A. Latar Belakang}

Pengertian perkawinan dalam Undang-Undang Nomor 1 Tahun 1974 Tentang Perkawinan yang tercantum dalam Pasal 1 (untuk selanjutnya disebut UndangUndang Perkawinan). Perkawinan ialah ikatan lahir dan batin antara seorang pria dengan seorang wanita sebagai suami istri dengan tujuan membentuk keluarga (rumah tangga yang bahagia dan kekal berdasarkan Ketuhanan Yang Maha Esa)". 1) Perkawinan merupakan suatu ikatan yang sah untuk membina rumah tangga dan keluarga sejahtera bahagia dimana kedua suami istri memikul amanah dan tanggung jawab, si isteri oleh karenanya akan mengalami suatu proses psikologis yang berat yaitu kehamilan dan melahirkan yang meminta pengorbanan. Sahnya perkawinan menurut perundangan yang diatur dalam Pasal 2 ayat (1) Undang- Undang Perkawinan yang menyatakan "Perkawinan adalah sah, apabila dilakukan menurut hukum masing-masing agamanya dan kepercayaannya itu". Jadi perkawinan yang sah menurut hukum perkawinan nasional adalah perkawinan yang dilaksanankan menurut tata tertib hukum yang berlaku dalam agama Islam, Kristen, Hindu/Budha. Kata "hukum masing-masing agamanya" berarti hukum dari salah satu agama masing-masing, bukan berarti "hukum agamanya masing-masing" yaitu hukum agama yang dianut oleh kedua mempelai atau keluarganya. Dalam kehidupan di masyarakat banyak terjadi perkawinan tanpa adanya pencatatan oleh negara, atau yang dikenal nikah siri $^{2}$. Nikah siri merupakan persoalan aktual yang patut untuk diperbincangkan. Dalam berbagai seminar dan diskusi, tema nikah siri seringkali dikemukakan hanya karena keberadaannya yang kontroversial. Pada satu sisi ada yang beranggapan nikah siri adalah sah menurut pandangan agama, namun pada sisi lain tidak sedikit yang

\footnotetext{
1 ) Mulati, Hukum Perkawinan Islam, (Tangerang, PT Pustaka Mandiri, 2012), hal 1.

2 ) Menurut Kamus Besar Bahasa Indonesia (KBBI) penyebutan kalimat nikah siri yang benar adalah dengan menggunakan satu huruf " $r$ ". Sedangkan dalam bahasa Arab sirri memakai dua huruf " $r$ " yang berasal dari kata sirr atau sirrun yang berarti sembunyi, dengan ini penulis menggunakan kalimat nikah siri yang terdapat dalam Kamus Besar Bahasa Indonesia.
} 
"menggugat" nikah siri lantaran dampak negatif yang ditimbulkan akibat tidak memiliki kekuatan hukum secara formal ${ }^{3)}$.

Memang melaksanakan perkawinan merupakan hak asasi setiap warga Negara, penegasan tersebut dapat dijumpai pada Pasal 28 B ayat (1) UndangUndang Dasar 1945 hasil perubahan kedua. Dalam pasal tersebut dinyatakan bahwa: "Setiap orang berhak membentuk keluarga dan melanjutkan keturunan melalui perkawinan yang sah". Meskipun perkawinan merupakan hak asasi, bukan berarti bahwa setiap warga Negara secara bebas dapat melaksanakan perkawinan, tapi harus mengikuti aturan peraturan perundangan yang berlaku di Negara Indonesia, salah satu diantaranya perkawinan dicatatkan di KUA yang dibuktikan dengan Akta Perkawinan. Fenomena yang terjadi saat ini adalah banyak praktek nikah siri, latar belakang terjadinya perkawinan ini ada berbagai alasan

diantaranya:

a. Adanya pandangan bahwa pernikahan yang telah dilakukan berdasarkan agama yang telah memenuhi syarat dan rukun perkawinan, maka perkawinan tersebut dianggap sah, sehingga tidak perlu lagi mencatatkan.

b. Sengaja menghilangkan jejak, sehingga babas dari tuntutan hukum dan cbhukuman administrasi dari instansinya, atau bahkan takut di ketahui istri tua sehingga memilih poligami yang tidak sesuai dengan peraturan. Akhir-akhir ini praktek perkawinan yang tidak tercatatkan atau nikah sirri banyak menimbulkan problem bagi keluarga itu sendiri, dikala perkawinan siri tersebut mempunyai anak, kemudian anak perlu Akta kelahiran untuk keperluan sekolah, kerja dan seterusnya, sementara disisi lain istri dari hasil Nikah Sirri butuh kepastian hukum baik dimata masyarakat maupun Negara,

\footnotetext{
3) Burhanuddin S, Menjawab Semua Pertanyaan tentang Nikah Siri, (Yogyakarta, Pustaka
} Yustisia, 2010). 
problematika nikah sirri akan lebih sulit jika nikah siri tersebut terjadi pada istri kedua,ketiga dan seterusnya ${ }^{4}$.

Ahmad Warson Munawwir dalam kamus besar Arab-Indonesia mengartikan istilah itsbat dengan penetapan, penutupan dan pengiyaan. Itsbat nikah menurut Keputusan Ketua Mahkamah Agung Republik Indonesia Nomor KMA/032/SK/2006 tentang Pedoman Pelaksanaan Tugas dan Administrasi Pengadilan adalah pengesahan atas perkawinan yang telah dilangsungkan menurut syariat agama Islam, akan tetapi tidak dicatat oleh Kantor Urusan Agama atau Pegawai Pencatat Nikah yang berwenang. Itsbat nikah juga mengandung arti suatu metode atau cara dalam menetapkan sahnya suatu perkawinan yang belum tercatat di Kantor Urusan Agama setempat, sesuai dengan ketentuan-ketentuan hukum yang berlaku terkait dengan hal perkawinan yang dilaksanakan di pengadilan. Buku Pedoman Teknis Administrasi Peradilan Agama Tahun 2010 menjelaskan bahwa itsbat nikah adalah pernyataan tentang sahnya perkawinan yang dilangsungkan berdasarkan agama dan tidak dicatat oleh Pegawai Pencatat Nikah yang berwenang ${ }^{5)}$. Namun oleh karena itsbat nikah sangat dibutuhkan oleh masyarakat, maka hakim Pengadilan Agama melakukan "ijtihad", kemudian mengabulkan permohonan itsbat nikah berdasarkan ketentuan Pasal 7 Ayat 3 huruf e KHI yang berbunyi "perkawinan yang dilakukan oleh mereka yang tidak mempunyai halangan perkawinan menurut Undang-Undang Nomor 1 Tahun 1974 Tentang Perkawinan”, pasal tersebut adalah dasar bagi pasangan yang melakukan nikah siri untuk mengajukan permohonan itsbat. Berdasar atas pertimbangan mudharatnya nikah siri tersebut, maka ijtima' ulama komisi fatwa Majelis Ulama Indonesia memutuskan, bahwa pernikahan harus dicatatkan secara resmi pada instansi berwenang, sebagai langkah preventif untuk menolak dampak negativ/mudharat (saddan lidz-dzari'ah), namun

\footnotetext{
${ }^{4)}$ H.Suhandak, "Problematika Isbat Nikah Isteri Poligami Dalam Penyelesaian Pengadilan Agama", https://app.box.com/s/isp3x2azh1, 1 April 2018.

$5)$ Mahkamah Agung, Pedoman Teknis Administrasi dan Teknis Peradilan Agama, (Jakarta, 2010), hal 147.
} 
nikah siri tersebut hukumnya sah karena telah memenuhi syarat dan rukun nikah, tetapi haram jika terdapat mudharat ${ }^{6)}$.

Tujuan dan manfaat dari adanya itsbat nikah adalah untuk mendapatkan kepastian dan perlindungan hukum bagi masing-masing pasangan suami istri terhadap terjadinya suatu perkawinan sehingga dengan adanya kepastian hukum dan perlindungan hukum dapat mempermudah dalam segala hal seperti sebagai bukti sahnya penikahan, untuk menjamin hak-hak dalam pernikahan jika terjadi perceraian termasuk hak memperoleh warisan dan hak pensiun serta perlindungan terhadap status anak yang lahir dari perkawinan itu dan perlindungan terhadap akibat hukum yang akan muncul kemudian hari salah satunya dalam hal pembuatan akta kelahiran ${ }^{7)}$.

Dengan mencermati jalan perkara berbagai kasus, terutama kasus yang berkaitan dengan perkawinan di bawah tangan, menunjukan betapa pentingnnya sosialisasi hukum Islam ke dalam masyarakat yang bukan saja bentuk rumusan hukum normatifnya, tetapi juga terutama tentang aspek tujuan hukum yang dalam kajian hukum Islam dikenal dengan maqasid asysyari'ah. Secara teoritis, hukum Islam dirumuskan oleh perumusnya (Allah).

Hal ini terjadi pada putusan Pengadilan Agama Nomor 1478/Pdt.G/PAJT Pengugat sebagai istri yang tidak diketahui identitasnya mengajukan gugatan cerai kepada tergugat yaitu suaminya, mereka menikah secara sirri pada tanggal 28 Nopember 1997 di Kantor Urusan Agama Jakarta Timur. Namun perkawinan mereka belum dicatatkan oleh Kantor Urusan Agama sehingga untuk mendapatkan Akta Perkawinan mereka juga mengajukan isbat nikah, pengugat mengajukan gugatan cerai kepada Pengadilan Agama Jakarta Timur dengan alasan perselisihan dan pertengkaran antara penggugat dan tergugat sejak tahun 2012, dan perselingkuhan yang dilakukan oleh tergugat. Namun di

\footnotetext{
${ }^{6)}$ Drs. H. Masrum M Noor, MH., Penetapan Pengesahan Perkawinan (Itsbat Nikah) Bagi Warga Negara Indonesia Di Luar Negeri, http://pajakartapusat.go.id/weblama/images/PENETAPAN_PENGESAHAN_PERKAWINAN.pdf

${ }^{7)}$ Pemberdayaan Perempuan Kepala Keluarga (PEKKA), "Panduan Pengajuan Itsbat Nikah", (Laporan Penelitian--Jakarta, Australia Indonesia partnership, 2012), hal 2.
} 
dalam putusan Pengadilan Agama Jakarta Timur dengan nomor regristrasi 1478/Pdt.G/2016/PAJT menolak pengajuan isbat nikah dengan alasan bahwa tergugat belum meminta izin kepada istri pertama dan pengadilan agama, sehingga sekaligus menolak gugatan cerai yang diajukan oleh penggugat.

\section{B. Permasalahan}

Bagaimana akibat hukum penolakan permohonan itsbat nikah oleh Pengadilan Agama terhadap para pihak yang melakukan nikah siri (Studi Putusan Nomor : 1478/Pdt.G/2016/PAJT) ?

\section{Metedologi Penulisan}

\section{Jenis Penelitian}

Metode penelitian yang penulis gunakan dalam penelitian ini adalah penelitian hukum normatif. Penelitian hukum normatif adalah suatu proses untuk menemukan suatu aturan hukum, asas-asas hukum, maupun doktrin-doktrin hukum untuk menjawab permasalahan hukum yang dihadapi. Penelitian hukum adalah suatu proses untuk menemukan aturan hukum prinsip-prinsip hukum, maupun doktrindoktrin hukum guna menjawab isu hukum yang dihadapi. ${ }^{8)}$

Dalam penelitan hukum terdapat beberapa pendekatan. Dengan pendekatan tersebut, peneliti akan mendapatkan informasi dari berbagai aspek mengenai isu yang sedang dicoba untuk dicari jawabanya. Penelitian ini menggunakan pendekatan perundangundangan (Statute Approach) dan pendekatan kasus (Case Approach).Pendekatan perundang-undangan (Statute Approach) hal ini dimaksudkan bahwa peneliti menggunakan peraturan perundangundangan sebagai dasar awal melakukan analisis. ${ }^{9}$ Pendekatan Kasus (Case Approach) pendekatan kasus dalam penelitian hukum normatif

\footnotetext{
${ }^{8}$ Mukti Fajar ND dan Yulianto Achmad, Dualisme Penelitian Hukum Normatif \& Empiris, Cetakan ke-1, Yogyakarta, Pustaka Pelajar, 2010, Hal.34.

${ }^{9}$ Ibid., Hal. 185.
} 
bertujuan untuk mempelajari norma-norma atau kaidah hukum yang dilakukan dalam praktik hukum. ${ }^{10)}$

\title{
2. Jenis dan Sumber Data Penelitian
}

Sumber data penelitian yang Penulis peroleh yaitu berasal dari studi kepustakaan dengan mengkaji bahan hukum. Bahan hukum yang diperoleh Penulis sebagai bahan untuk melakukan penelitian diambil dari data kepustakaan, yang terdiri dari bahan hukum primer, bahan hukum sekunder dan bahan hukum tersier, adapun bahannya sebagai berikut:

Bahan hukum primer yaitu bahan-bahan yang isinya mempunyai kekuatan yang mengikat kepada masyarakat. Dalam penulisan ini bahan primer yang penulis gunakan yaitu:
a. Undang-Undang Dasar Negara Republik Indonesia Tahun 1945
b. Undang-Undang Nomor 1 Tahun 1974 Tentang Perkawinan
c. Peraturan Pemerintah Nomor 9 Tahun 1975 Tentang Pelaksanaan Undang-Undang Perkawinan

d. Kompilasi Hukum Islam

Bahan Hukum Sekunder, yaitu bahan-bahan hukum yang memberikan penjelasan mengenai bahan hukum primer, yang dapat berupa rancangan perundang-undangan, hasil penelitian, buku-buku teks, jurnal ilmiah. ${ }^{11)}$

Bahan Tersier, yaitu bahan hukum yang dapat menjelaskan baik bahan hukum primer maupun bahan hukum sekunder, yang berupa kamus, ensiklopedi, leksikon dan lain-lain. Dalam penulisan ini bahan hukum tersiernya adalah kamus besar Bahasa Indonesia.

\section{Teknik Pengumpulan Data}

\author{
10) Ibid., Hal. 190. \\ 11 )Ibid., Hal. 157-158.
}


Dalam penelitian Hukum Normatif atau kepustakaan teknik pengumulan data dalam penelitian hukum normatif dilakukan dengan studi pustaka terhadap bahan-bahan hukum, baik bahan hukum primer, bahan hukum sekunder, maupun bahan hukum tersier dan atau bahan non-hukum. Penelusuran bahan-bahan hukum tersebut dapat dilakukan dengan membaca, melihat, mendengarkan, maupun sekarang banyak dilakukan penelusuran bahan hukum tersebut dengan melalui media internet. ${ }^{12)}$

\section{Teknik Pengolahan Data}

Bahan hukum pengolahan bahan dalam penelitian hukum normatif berwujud kegiatan untuk mengadakan sistematisasi terhadap bahanbahan hukum tertulis. Dalam hal ini pengolahan bahan dilakukan dengan cara, melakukan seleksi data sekunder atau bahan hukum, kemudian melakukan klasifikasi menurut penggolongan bahan hukum dan menyusun data hasil penelitian tersebut secara sistematis, tentu saja hal tersebut dilakukan secara logis artinya ada hubungan dan keterkaitan antara bahan hukum satu dengan bahan hukum lainnya untuk mendapatkan gambaran umum dari hasil penelitian. ${ }^{13)}$

\section{Teknin Analisis Data}

Analisis data merupakan kegiatan dalam penelitian yang berupa melakukan kajian atau telaah terhadap hasil pengolahan data yang dibantu dengan teori-teori yang telah didapatkan sebelumnya. Secara sederhana analisis data ini disebut sebagai kegiatan memberikan telaah, yang dapat berarti menentang, mengkritik, mendukung, menambah atau memberi komentar dan kemudian membuat suatu

\footnotetext{
12 ) Ibid., Hal. 160.

${ }^{13}$ ) Ibid., Hal. 181.
} 
kesimpulan terhadap hasil penelitian dengan pemikiran sendiri dan bantuan teori yang telah dikuasainya. ${ }^{14)}$

\section{Pembahasan}

\section{A. Kasus Posisi}

Bahwa pada hari Jum'at tanggal 28 Nopember 1997, telah berlangsung perkawinan antara Penggugat dan Tergugat di wilayah hukum Kantor Urusan Agama di Jakarta Timur.

Penggugat tidak memiliki buku nikah, karena pernikahan Penggugat dan Tergugat dilakukan secara siri, tidak dihadiri oleh pegawai atau pejabat dari Kantor Urusan Agama sehingga tidak tercatat di Kantor Urusan Agama.

Pada saat akad nikah Penggugat berstatus perawan dan Tergugat berstatus beristri, namun penggugat mengetahui nama istri Tergugat, bahwa pada saat akad nikah, tidak ada izin dari istri terdahulu maupun dari Pengadilan Agama, perkawinan tersebut dihadiri oleh dua orang saksi dan yang menjadi wali adalah ayah Tergugat.

Bahwa selama pisah antara Penggugat dan Tergugat tidak ada yang berusaha untuk rukun kembali, bahkan Tergugat tidak pernah datang mengunjungi penggugat dan tidak pernah memberi nafkah kepada Penggugat. Bahwa Penggugat telah berupaya mengatasi masalah tersebut dengan jalan/cara bermusyawarah atau berbicara dengan Tergugat secara baik-baik tidak berhasil. Bahwa atas sikap dan perbuatan Tergugat tersebut penggugat sangat menderita lahir batin, sehingga rumah tangga antara Penggugat dan Tergugat tidak bisa dipertahankan lagi, Penggugat berkesimpulan lebih baik bercerai dengan Tergugat.

Dengan ini Tergugat telah melanggar Pasal 4 ayat (1) Undang-Undang Perkawinan karena untuk beristri dari seorang harus adanya permohonan ke Pengadilan Agama di daerah tempat tinggalnya dan Pasal 5 ayat (1)

\footnotetext{
${ }^{14}$ ) bid., Hal. 183.
} 
Undang-Undang Perkawinan tentang harus adanya persetujuan dari istri sebelumnya, sedangkan Tergugat tidak meminta persetujuan dari istri sebelumnya. Bahwa dengan demikian perkawinan poligami sebagaimana yang dilakukan oleh Penggugat dan Tergugat pada tanggal 28 Nopember 1997 tersebut adalah perkawinan yang tidak memenuhi syarat menurut Undang-Undang, oleh karena itu perkawinan tersebut merupakan perkawinan tidak sah.

Berdasarkan pada pertimbangan di atas, oleh karena perkawinan Penggugat dengan Tergugat tersebut tidak sah, maka gugatan Penggugat agar diceraikan dari Tergugat tidak memiliki dasar hukum yang sah, sehingga harus dinyatakan tidak dapat diterima.

\section{B. Hasil Wawancara}

1. Bapak Muhammad Abudan selaku Dosen Universitas Tarumanagara ${ }^{15)}$

Itsbat adalah penetapan, itsbat nikah adalah penetapan suatu perkawinan yang sebelumnya perkawinana tersebut belum tetap, dikarenakan perkawinan hanya dilangsungkan dengan peraturan agama saja, sebenarnya bagi seorang muslim yang mempunyai komitmen yang kuat tentang ketentuan-ketentuan agama, perkawinan berdasarkan peraturan agama saja sudah cukup tetapi tidak ada Akta Perkawinan, dengan adanya itsbat nikah ini perkawinan di bawah tangan atau nikah siri bisa mendapatkan pengakuan dari negara dan mendapatkan Akta Perkawinan. Kata itsbat di dalam suatu hadits memang ada, tetapi dalam Al-Quran kata itsbat tidak ditemukan, dalam hadits hanya dijelaskan mengenai itsbat saja dan tidak menjelaskan mengenai itsbat nikah, dan memang perlu dikaji tentang itsbat nikah dalam islam, karena di zaman Rasulullah tidak ada itsbat nikah. Di dalam hukum islam jika seorang suami ingin beristri lebih dari satu tidak perlu menggunakan izin dari seorang istri, tetapi kalau menurut Undang-

${ }^{15)}$ Peneliti, wawancara dengan Muammad Abudan, selaku dosen Universitas Tarumanagara, (Jakarta, 8 Juni 2018) 
Undang Perkawinan harus adanya izin dari istri/istri-istri sebelumnya dan menurut Pasal 58 ayat (1) KHI juga harus adanya izin dari istri/istri-istri sebelumnya.

2. Bapak Drs. H. Djuwadi selaku Hakim Ketua pada putusan perkara Nomor 1478/Pdt.G/2016/PAJT ${ }^{16)}$

Itsbat nikah itu adalah permohonan penetapan pengesahan perkawinan, sebetulnya yang disebut dengan itsbat nikah itu meminta kepada pengadilan agar perkawinan yang sudah dilakukan disahkan menurut hukum Indonesia, berarti yang mengajukan itsbat nikah Indonesia tidak mengikuti Undang-Undang Perkawinan yang ada di Indonesia, yang disebut perkawinan di bawah tangan, sehingga untuk memperoleh kepastian hukum maka meminta untuk disahkan atau ditetapkan perkawinannya, dalam istilahnya disebut itsbat nikah atau pengesahan perkawinan. Syarat-syarat mengajukan itsbat nikah yang menurut hukumnya orang yang melakukan perkawinan sebelum Undang-Undang Perkawinan, yang perkawinan tersebut dilakukan menurut hukum Islam, sehingga pada dasarnya orang-orang yang menikah setelah adanya Undang-Undang Perkawinan sebenarnya tidak dapat disahkan, kecuali ada hal-hal yang terdapat dalam KHI, namun akhir-akhir berkembang menjadi ada yang membolehkan.

Nikah dibawah tangan atau nikah siri pada dasarnya tidak boleh di Indonesia, tidak mempunyai kekutan hukum. Karena itu nikah di bawah tangan atau nikah siri adalah tidak dicatat dan diawasi Pejabat Pencatat Nikah, karena tidak diawasi rawan dengan pelanggaran atau tidak memenuhi syarat atau rukunnya, disitulah fungsinya Pejabat Pencatat Nikah untuk mengawasi perkawinan, intinya pada dasarnya perkawinan yang tidak dicatatkan dilarang tetapi masih banyak orang yang melakukan, kenapa dia melakukan nikah dibawah tangan atau nikah siri karena ada suatu atau hal-hal yang disembunyikan, karena

16) Peneliti Wawancara dengan Drs Djuwadi, S.H, M.H. , selaku Hakim Ketua pada putusan perkara Nomor 1478/Pdt.G/2016/PAJT, (Jakarta, 28 Juni 2018) 
dia akan menyimpang dari Undang-Undang Perkawinan itu sendiri, bisa jadi akan ada penyelundupan hukum. Perkawinan yang sebelum berlakunya Undang-Undang Perkawinan dan dilakukan menurut hukum Islam biasanya permohonan itsbat nikah dikabulkan, jika memenuhi syarat dan tidak bertentangan dengan hukum perkawinan islam. Akibat penolakan itsbat nikah itu adalah tidak diakui sebagai suami istri oleh negara, kalau terkait dengan anak, anak tersebut menjadi anak ibunya.

3. Ibu Mulati selaku Dosen Universitas Tarumanagara ${ }^{17)}$

Itsbat nikah itu sebenarnya adalah penetapan hakim agar setiap orang mempunyai akta perkawinan, dengan melakukan pencatatan terhadap perkawinan untuk mempunyai kekuataun hukum, artinya pencatatan tersebut hukumnya wajib, jika tidak ada pencatatan nanti anak yang akan lahir tidak dapat diakui, dengan bukti penetapan itu maka istri dan anak akan mendapatkan haknya. Karena jika tidak di istbatkan perkawinan tersebut, mereka tidak ada akta perkawinan, akibatnya tidak mendapatkan harta waris dan anaknya tidak mendapatkan akta perkawinan, jadi tugas Kantor Urusan Agam tersebut hanya mencatat, jika tidak ada ketetapan itsbat tidak bisa dicatat, jadi itsbat harus diajukan di Pengadilan Agama agar mendapatkan hak, jadi itsbat nikah itu sangat penting dalam pelaksanaan perkawinan yang tidak dicatat Akibatnya jika di tidak itsbat tersebut anaknya menjadi anak luar kawin, karena secara hukum tadi tidak penetapan hakim walaupun sah secara agama, karena negara Indonesia menganut hukum positive bahwa perkawinan harus dicatat, akibat tidak dicatat istri tidak mendapatkan waris.

4. Ibu Wahyuni Retno Wulandari, S.H, M.H selaku Dosen Universitas Trisakti ${ }^{18)}$

\footnotetext{
${ }^{17)}$ Peneliti, wawancara dengan Mulati, selaku dosen Universitas Tarumanagara, (Jakarta,
} 17 Juli 2018) 
Dilihat dari Pasal 7 ayat (3) huruf a jadi Itsbat nikah tersebut dilakukan dalam rangka untuk penyelesaian perceraian, dari sah atau tidaknya itu dilihat dari persyaratan perkawinannya sah atau tidak, akibat ditolaknya itsbat nikah oleh Pengadilan Agama perkawinanya menjadi tidak sah, berarti suami dan istri tidak mempunyai hak dan kewajiban, dan karena perkawinan tersebut tidak sah secara Undang-Undang Perkawinan dan KHI sebenarnya tidak dapat diajukan ke Pengadilan Agama, Namun di talak secara hukum Islam melalui lisan, dan anak tersebut menjadi anak tidak sah.

Jadi secara syariah yang dilihat adalah perkawinan sesuai rukun nikah atau tidak, jika perkawinan sudah sesuai dengan rukun maka perkawinan tersebut adalah sah, jika dilihat dari secara syariah anak yang lahir dalam perkawinan tersebut menjadi anak yang sah, kecuali perkawinannya tidak memenuhi rukun perkawinan makan perkawinan itu menjadi tidak sah, dan berarti juga anaknya berarti menjadi anak diluar kawin, tetapi walaupun tidak dibuat pesta atau tidak dicatatkan perkawinan tersebut tetap sah secara Islam jika memenuhi rukun, kalau bercerai secara Islam maka anak-anak tetap mendapat hadahanah yaitu uang yang harus diberikan untuk pengasuhan anak, kalau suami meninggal anak tersebut masih mendapatkan harta warisan secara syariah, jadi jika perceraian perkawinan tersebut mau diselesaikan secara syariat agama maka hak-hak istri dan anak-anaknya harus diberikan walaupun perkawinan tersebut kawin siri.

Jadi kalau menurut syariat sah tidak perlu mengajukan gugatan ke pengadila, jadi seharusnya laki-laki tersebut dengan sadar diri menyerahkan hak-hak untuk istri dan anak.

Sebenarnya itsbat nikah diperbolehkan untuk perkawinan yang dilakukan sebelum Undang-Undang Perkawinan, kecuali perkawinan

18 ) Peneliti, wawancara dengan Wahyuni Retno Wulandari, selaku dosen Universitas Tarumanagara, (Jakarta, 26 Juli 2018) 
yang tinggal jauh dari kegiatan administrasi dan tidak tau tentang Undang-Undang Perkawinan dan KHI itu karena ketidaktahuan mereka itu dapat diajukan itsbat nikah, tetap dalam kasus ini mereka mengetahui dan mereka sengaja.

\section{Analisis}

Perkawinan merupakan salah satu cara untuk menyalurkan naluri seksual antara suami istri secara halal, dan juga untuk memperoleh keturunan. Perkawinan juga merupakan perintah yang diperintahkan oleh agama untuk dikerjakan karena merupakan suatu ibadah.

Di Indonesia segala macam hal mengenai perkawinan telah diatur di dalam Undang-Undang Perkawinan, Peraturan Pemerintah Nomor 9 Tahun 1975 Tentang Pelaksanaan Undang-Undang Perkawinan, dan juga KHI.

Namun masih banyak masyarakat di Indonesia yang melakukan perkawinan yang tidak sesuai dengan peraturan yang berlaku di Indonesia atau yang disebut hukum positif, contohnya adalah perkawinan dibawah tangan atau yang biasa disebut oleh masyrakat sebagai perkawinan siri, yang di dalam masyarakat Indonesia perkawinan siri itu disebut yang tidak sah secara, karena perkawinan tersebut tidak dicatatkan, namun ada yang berpendapat perkawinan siri itu adalah tetap perkawinan yang sah dilihat dari sudut pandang agama.

Contoh pada kasus perkara gugatan cerai dan permohonan itsbat nikah di Pengadilan Agama Jakarta Timur dengan Nomor perkara 1478/Pdt.G/2016/PAJT, bahwa Tergugat melakukan perkawinan dengan Penggugat tanpa adanya izin dari istri Tergugat sebelumnya dan izin dari pengadilan, sehingga permohonan itsbat nikah dan gugatan cerai tidak dapat diterima oleh Pengadilan Agama Jakarta Timur, sehingga perkawinan itu disebut perkawinan di bawah tangan atau nikah siri. 
Untuk sahnya nikah siri ini pelaksanaannya seperti lazimnya perkawinan dalam agama Islam, maka diharuskan adanya seorang wali yang boleh menikahkan seorang perempuan dengan seorang laki-laki. Pada waktu pernikahan dilangsungkan sebagian besar subjek menjadikan ayahnya sendiri sebagai wali nikah, tetapi ada pula yang menggunakan saudara kandung. Perkawinan selain harus ada wali, syarat lain yang harus terpenuhi dalam perkawinan yaitu adanya saksi. Saksi yang hadir dalam pelaksanaan nikah siri selain dua orang laki-laki juga ada subjek yang menghadirkan dua orang perempuan atau satu orang laki-laki. Perkawinan seperti itu dipandang tidak memenuhi ketentuan peraturan perundang-perundangan dan seringkali menimbulkan dampak negatif (madharat) terhadap istri dan atau anak yang dilahirkannya terkait dengan hak-hak mereka seperti nafkah, hak waris dan lain sebagainya. Tuntutan pemenuhan hak-hak tersebut manakala terjadi sengketa akan sulit dipenuhi akibat tidak adanya bukti catatan resmi perkawinan yang sah. Menurut pendapat penulis pada perkawinan yang dilakukan oleh Tergugat dan Penguggat yang sudah sah secara agama namun tidak dicatatkan di Kantor Urusan Agama, maka nikah sirih ini termasuk nikah siri yang tidak dicatatkan, walaupun tidak dicatatkan perkawinannya dari aspek menurut hukum Islam sudah sah secara agama dan para pihak yang melakukannya tidak boleh dianggap melakukan perbuatan maksiat, karena pada dasarnya fungsi pencatatan perkawinaan pada lembaga pencatatan sipil adalah agar seseorang memiliki alat bukti (bayyinah) untuk membuktikan bahwa dirinya benar-benar telah melakukan perkawinan dengan orang lain.

Menurut fatwa Majelis Ulama Indonesia Nomor 10 Tahun 2008 Tentang Nikah di bawah tangan atau yang biasa disebut dengan nikah siri dipandang tidak memenuhi ketentuan peraturan perundang-perundangan dan seringkali menimbulkan dampak negatif (madharat) terhadap istri dan atau anak yang dilahirkannya terkait dengan hak-hak mereka seperti nafkah, hak waris dan lain sebagainya. Tuntutan pemenuhan hak-hak tersebut manakala terjadi 
sengketa akan sulit dipenuhi akibat tidak adanya bukti catatan resmi perkawinan yang sah.

Dalam perkara tersebut Tergugat saat melangsungkan perkawinan dengan Penggugat, Tergugat masih mempunyai istri sehingga dalam hal ini Tergugat melakukan poligami atau ingin mempunyai istri lebih dari seorang, namun tidak sesuai dengan yang dinyatakan dalam undang-undang baik UndangUndang Perkawinan maupun dalam KHI. Perkawinan yang dilaksanakan sebenarnya telah memenuhi konsep dan syarat-syarat dari rukun islam, konsep perkawinan tersebut dijelaskan di dalam Al-Qur'an, hadits Nabi dan beberapa pendapat dari imam-imam mazhab.

Pasal 3 ayat (2) Undang-Undang Perkawinan menyatakan di dalam penjelasannya bahwa "pengadilan dalam memberi putusan selain memeriksa apakah syarat yang tersebut dalam Pasal 4 dan 5 telah dipenuhi harus mengingat pula apakah ketentuan-ketentuan hukum perkawinan dari calon suami mengizinkan adanya poligami. Dalam hal seorang suami akan beristri lebih dari seoranag, maka ia wajib mengajukan permohonan kepada pengadilan di daerah tempat tinggalnya. Pengadilan dimaksud hanya memberi izin kepada seorang suami apabila beralasan sebagai berikut (perhatikan Pasal 4 ayat (1) s.d (2) Undang-Undang Perkawinan;):

1. Dalam hal seorang suami akan beristri lebih dari seorang, sebagaimana tersebut dalam pasal 3 ayat (2) Undang-undang ini, maka ia wajib mengajukan permohonan ke Pengadilan di daerah tempat tinggalnya.

2. Pengadilan dimaksud dalam ayat (1) pasal ini hanya memberi izin kepada suami yang akan beristri lebih dari seorang apabila:

1) Istri tidak dapat menjalankan kewajibannya sebagai seorang istri;

2) Istri mendapat cacat badan atau mempunyai penyakit yang tidak dapat disembuhkan;

3) Tidak dapat melahirkan. 
Tetapi dengan alasan-alasan tersebut tadi bagi si pemohon belum cukup dapat diterima oleh pengadilan, oleh karena pengadilan masih akan memeriksa sebagai berikut yang dijelaskan dalam Pasal Undang-Undang Perkawinan.:

1. Ada atau tidaknya persetujuan istri, baik persetujuan lisan maupun tertulis, apabila persetujuan itu merupakan persetujuan lisan, persetujuan itu harus diucapkan di depan sidang pengadilan;

2. Ada atau tidaknya kemampuan suami untuk menjamin keperluan hidup istri-istri dan anak-anak dengan memperhatikan surat-surat mengenai penghasilan suami yang ditandatangani oleh bendahara tempat bekerja, atau surat keterangan pajak penghasilan, atau surat keterangan lain yang dapat diterima oleh pengadilan;

3. Ada atau tidaknya jaminan bahwa suami akan berlaku adil terhadap istriistri dan anak-anak mereka dengan pernyataan atau janji dari suami yang dibuat dalam bentuk yang ditetapkan untuk itu ${ }^{19)}$.

Tentang diperlukannya adanya persetujuan dari istri-istri untuk memperkenankan suaminya kawin lagi dengan wanita lain, apabila ternyata istri/ istri-istri yang akan diminta persetujuan tidak mungkin memberikan persetujuannya, dikarenakan misalnya sakit keras, gila, dan sebagainya, atau karena istri/ istri-istri itu tidak dapat menjadi pihak dalam perjanjian atau karena tidak ada kabar lagi dari istrinya selama sekurang-kurangnya dua tahun, atau karena sebab-sebab lain yang perlu dinilai oleh hakim, maka persetujuan istri/ istri-istri itu tidak diperlukan bagi suami yang akan kawin lagi itu (Pasal 5 ayat 2 Undang-Undang Perkawinan).

Dalam perkara tersebut Penggugat mengajukan permohonan yang disebut dengan itsbat nikah, Itsbat nikah berasal dari bahasa Arab dan terdiri dari dua kata "itsbat" dan "nikah". Itsbat artinya penetapan, pengukuhan dan pengekalan. Jadi itsbat nikah berarti penetapan atau pengukuhan nikah, yakni itsbat nikah merupakan penetapan ulang terhadap pernikahan yang sudah

19 ) Prof. H. Hilman Hadikusuma, Hukum Perkawinan Indonesia, (Bandung, Mandar Maju, 2007) hal 32-34. 
dilakukan, karena adanya keraguan terhadap keabsahan perkawinan tersebut, atau keberadaan pernikahan itu tidak dapat dibuktikan dengan akta otentik (akta perkawinan). Syarat-syarat mengajukan itsbat nikah yang menurut hukumnya orang yang melakukan perkawinan sebelum Undang-Undang Perkawinan, yang perkawinan tersebut dilakukan menurut hukum Islam, sehingga pada dasarnya orang-orang yang menikah setelah adanya UndangUndang Perkawinan sebenarnya tidak dapat disahkan, kecuali ada hal-hal yang terdapat dalam KHI.

Dalam Pasal 7 KHI terdapat beberapa dapat alasan diajukannya itsabat nikah yaitu:

1. Perkawinan hanya dapat dibuktikan dengan Akta Nikah yang dibuat oleh Pegawai Pencatat Nikah.

2. Dalam hal perkawinan tidak dapat dibuktikan dengan Akta Nikah, dapat dijaukan itsbat nikahnya ke Pengadilan Agama.

3. Itsbat nikah yang dapat diajukan ke Pengadilan Agama terbatas mengenai hal-hal yang berkenaan dengan :

a. Adanya perkawinan dalam rangka penyelesaian perceraian;

b. Hilangnya Akta Nikah;

c. Adanya keraguan tentang sah atau tidaknya salah satu syarat perkawinan;

d. Adanya perkawinan yang terjadi sebelum berlakunya UndangUndang Perkawina dan;

e. Perkawinan yang dilakukan oleh mereka yang tidak mempunyai halangan perkawinan menurut Undang Undang Perkawinan. 
4. Yang berhak mengajukan permohonan itsbat nikah ialah suami istri, anakanak mereka, wali nikah dan pihak yang berkepentingan dengan perkawinan itu.

Itsbat nikah atau pengesahan nikah merupakan salah satu perkara yang menjadi kewenangan Pengadilan Agama dan dikelompokkan dalam perkara yang mengandung unsur sengketa (Voluntair Jurisdiction) di mana hanya ada satu pihak yang berkepentingan, yaitu pemohon dan produknya adalah penetapan.

Dengan adanya lembaga itsbat nikah ini merupakan sebagai pencegah agar tidak terjadi kekurangan dan penyimpangan rukun dan syarat perkawinan baik menurut syara' maupun perundang-undangan, dan juga untuk menjaga hak-hak istri dan anak-anak untuk mendapatkan hak nafkah, hak untuk mewaris dan lain sebagainya.

Ada dua macam manfaat yang terdapat di dalam itsbat nikah:

1. Manfaat preventif, yaitu untuk menanggulangi agar tidak terjadi kekurangan atau penyimpangan rukun dan syarat-syarat pernikahan, baik menurut hukum agama dan kepercayaannya maupun menurut perundangundangan.

2. Manfaat represif, yaitu dimaksudkan untuk membantu masyarakat agar di dalam melangsungkan perkawinan tidak hanya mementingkan aspekaspek hukum fiqh saja, tetapi aspek-aspek keperdataan juga perlu diperhatikan secara seimbang ${ }^{20)}$.

Namun pada kasus yang penulis jelasakan bahwa di dalam putusan Pengadilam Agam Jakarta Timur menolak permohonan istbat nikah yang diajukan guna untuk menyelesaikan gugatan perceraian para pihak .

\footnotetext{
${ }^{20)}$ Ahmad Rafiq, Hukum Islam di Indonesia, (Jakarta, PT.Raja Grafindo Persada, 1995),
} hal.111-117. 
Oleh karena itu dampak ditolaknya permohonan itsbat nikah berakibat kepada status perkawinan, status anak, dan juga status harta yang di dapatkan selama perkawinan.

Akibat penolakan itsbat nikah oleh Pengadilan Agama terhadap status perkawinan antara Penggugat dan Tergugat walaupun sah secara agama namun perkawinan tersebut tidak diakui oleh negara, karena tidak adanya Akta Perkawinan atau putusan dari pengadilan sehingga tidak mempunyai kekuatan hukum, dikarenakan Akta Perkawinan dan putusan dari pengadilan merupakan bukti otentik bahwa telah terjadi perkawinan antara para pihak. dengan ditolaknya itsbat nikah tersebut oleh Pengadilan Agama maka status perkawinan antara Penggugat dan Tergugat tersebut tidak sah secara negara, sehingga suami tersebut tidak mempunyai kewajiban dan hak secara UndangUndang Perkawinan dan KHI terhadap istrinya, dan begitu juga dengan istrinya tidak mempunyai hak dan kewajiban terhadap suaminya menurut Undang-Undang Perkawinan dan KHI, akan tetapi menurut hukum agama Islam suami tetap mempunyai kewajiban dan hak, sama halnya dengan istri yang juga mempunya kewajiban dan hak terhadap suaminya. Begitupun dengan status anak, Seorang anak yang lahir melalui proses perkawinan yang sah baik berdasarkan hukum agama, maupun hukum negara menyandang predikat sebagai anak sah, demikian pula sebaliknya jika seorang anak yang lahir tidak melalui proses perkawinan yang sah akan menyandang predikat sebagai anak tidak sah yakni anak luar nikah (anak zina).

Demikian halnya nikah di bawah tangan atau "nikah siri" yakni perkawinan yang tidak disertai pencatatan di hadapan penghulu agama. Perkawinan seperti ini bertentangan dengan Undang-Undang. Perkawinan yang melalui prosudur dan ketentuan hukum yang benar akan melahirkan anak sah. Menurut UndangUndang Perkawinan, Pasal 42 berbunyi "Anak yang sah adalah anak yang dilahirkan dalam atau sebagai akibat perkawinan yang sah" Dalam KHI Pasal 99 disebutkan bahwa anak sah adalah anak yang dilahirkan dalam atau akibat perkawinan yang sah, hasil perbuatan suami isteri yang sah 
di luar rahim dan dilahirkan oleh isteri tersebut. Suatu perkawinan menjadi sah menurut perundang-undangan yang telah diatur dalam Pasal 2 ayat (1) Undang-Undang Perkawinan menyatakan "perkawinan adalah sah apabila dilakukan menurut hukum masing-masing agamanya dan kepercayaannya itu. Karena itu perkawinan yang sah menurut hukum perkawinan nasional adalah perkawinan yang dilaksanakan menurut hukum yang berlaku setiap agama.

Berdasarkan pada ketentuan Pasal 2 ayat (2) Undang-Undang perkawinan, disatukan dengan urusan administrasi, yakni masalah pencatatannya. Ijab kabul dan persaksian nikah oleh dua orang saksi dan pencatatan menjadi satu kesatuan yang tidak boleh dipisah-pisahkan. sehingga tercipta adanya suatu kepastian hukum. Inilah yang dijadikan pegangan dalam pelaksanaan perkawinan di Indonesia, sehingga menjadi hukum perkawinan nasional dan anak yang lahir dari hasil perkawinan tersebut dikategorikan sebagai anak $\operatorname{sah}^{21)}$.

Sedangkan status hukum anak luar kawin hanya mempunyai hubungan keperdataan dengan ibu dan keluarga ibunya saja, sedangkan dengan ayah biologis dan keluarganya, anak luar kawin sama sekali tidak mempunyai hubungan keperdataan. Demikian halnya pembuatan identitas diri anak berupa akta kelahiran tidak boleh dibuatkan.

Dalam hal harta bersama yang menurut Pasal 35 Undang-Undang Perkawinan adalah "Harta benda diperoleh selama perkawinan menjadi harta bersama". Sedangkan dalam KHI di Bab 1 Ketentuan Umum di Pasal 1 huruf (f) menyebutkan bahwa : "Harta kekayaan dalam perkawinan atau syirkah adalah harta yang diperoleh baik sendiri-sendiri atau bersama suami istri selama dalam perkawinan berlangsung selanjutnya disebut harta bersama”.

\footnotetext{
${ }^{21)}$ Aisyah Rasyid, "Problematika Anak Sah Dalam Prespektif Hukum Nasional Dan Putusan MK Nomor 46 Tahun 2010", Vol II, hal. 223.
} 
Kemudian melalui Pasal 91 KHI menegaskan bahwa yang termasuk dalam lingkup harta bersama adalah benda berwujud dan tidak berwujud. Benda berwujud meliputi :

1. Benda tidak bergerak. Seperti rumah, tanah, pabrik.

2. Benda bergerak, seperti perabot rumah tangga, mobil.

3. Surat-surat berharga, seperti obligasi, deposito, cek, bilyet giro, dll.

Adapun benda yang tidak berwujud berupa:

1. Hak Seperti hak tagih terhadap piutang yang belum dilunasi,hak sewa yang belum jatuh tempo.

2. Kewajiban, Seperti kewajiban membayar kredit, melunasi hutanghutang.

Terhadap semua bentuk dan jenis harta bersama tersebut apabila dilakukan transaksi harus atas persetujuan bersama suami istri. Ketentuan tersebut diatur dalam Pasal 36 ayat (1)Undang-Undang Perkawinan, yang berbunyi “ Mengenai harta bersama, suami istri dapat bertindak atas persetujuan kedua belah pihak”. Dalam Kompilasi Hukum Islam Pasal 92 disebutkan " Suami atau istri tanpa persetujuan pihak lain tidak diperbolehkan menjual atau memindahkan harta bersama““.22) Pasal 37 Undang-Undang Perkawinan mengatur tentang harta benda apabila perkawinananya putus akibat perceraian, yang berbunyi " Bila perkawinan putus karena perceraian, harta benda diatur menurut hukumnya masing-masing”.

Jadi harta bersama adalah harta yang dikumpulkan baik suami dan juga istri selama perkawinan tersebut berlangsung, sehingga baik suami ataupun istri yang ingin melakukan suatu perbuatan hukum terhadap benda harta bersama terseebut harus mendapat persetujuan baik istri maupun suami.

\section{Penutup}

\footnotetext{
${ }^{22)}$ Muhammad Nur, "Kedudukan Harta Bersama Dalam Prespektif Hukum Islam", Vol 1
} No. 3, Tahun 2013, hal. 65. 


\section{A. Kesimpulan}

Kesimpulan penulis di dalam penulisan ini adalah bahwa perkawinan merupakan upaya untuk menyalurkan hasrat seksual suami istri, dan juga untuk memperoleh keturunan, namun perkawinan tersebut harus dilakukan sesuai dengan Undang-Undang Perkawinan yang salah satu syaratnya perkawinan tersebut harus dicatatkan, sesuai dengan isi Pasal 2 ayat (2) Undang-Undang Perkawinan, bahwa "Tiap-tiap perkawinan harus dicatatkan menurut peraturan perundang-undangan yang berlaku".

itsbat nikah adalah suatu cara bagi pasangan suami istri yang menikah sah secara agama atau nikah siri untuk mendapatkan akta perkawinan, dan menjamin status perkawinan mereka, juga menjamin status anak yang lahir didalam perkawinan tersebut. Itsbat nikah yang tidak sesuai dengan ketentuan peraturan perundang-undangan dapat ditolak oleh Pengadilan Agama, itsbat nikah harus dilakukan sesuai dengan ketentuan peraturan perundangundangan yang berlaku, dalam hal penulisan ini tidak adanya izin dari istri dan pengadilan.

Dampak yang ditimbulkan dari penolakan tersebut adalah status perkawinan suami istri tersebut tidak sah secara negara, sehingga suami dan istri tidak mempunyai hak dan kewajiban sebagai suami istri menurut negara, dan juga anak yang dilahirkan dalam perkawinan tersebut dianggap anak luar kawin oleh negara.

Penulis dalam kesimpulan ini berpendapat, bahwa apa yang telah dilakukan oleh hakim Pengadilan Agama tersebut sudah benar, yaitu menolak permohonan itsbat nikah, di karenakan suami tidak meminta izin dari istri sebelumnya dan pengadilan seperti yang tercantum di dalam Pasal 4 ayat (1) Undang-Undang Perkawinan, tetapi akibat dari penolakan ini adalah status perkawinan dan status anak tidak sah secara negara, sehingga hal itu berdampak kepada istri dan anak yang tidak mendapatkan hak-haknya.

\section{B. Saran}


1. Penulis memberi saran walaupun itsbat mereka ditolak yang menyebakan perkawinan mereka dianggap tidak sah menurut Undang-Undang Perkawinan dan KHI, sehingga pihak istri dan anak tidak mempunyai jaminan atas hak-hak mereka, apabila pihak suami mempunyai itikad baik maka bisa diselesaikan menurut hukum Islam, sehingga istri dan anak mendapatkan hak-haknya.

2. Penulis berpedapat terhadap perkawinan yang terjadi di indonesia, adalah masih kurangnya pengawasan terhadap pencatatan perkawinan. Jadi saran dari penulis adalah harus lebih ketatnya pengawasan terhadap perkawinanperkawinan yang terjadi di Indonesia, dan juga pentingnya sosialisasi baik di kota-kota terutama di daerah-daerah pelosok oleh pemerintah atau lembaga-lembaga sosial mengenai nikah siri dan pentingnya untuk mencatatkan perkawinan mereka, dikarenakan jika tidak dicatat perkawinan akan menimbulkan ketidakpastian hukum dan tidak menjamin hak istri dan anak, juga pentingnya mensosialisasikan mengenai itsbat nikah, apabila sudah terjadi perkawinan yang secara sah agama tetapi belum dicatatakan, maka harus mengajukan permohonan itsbat nikah untuk menjamin kepastian hukum hak-hak istri dan anak, tetapi permohonan tersebut harus sesuai dengan peraturan perundang-undangan yang berlaku.

\section{Daftar Pustaka}

\section{A. Buku}

Hadikusuma, H. Hilman. Hukum Perkawinan Indonesia. Bandung: Mandar Maju, 2007.

S,Burhanuddin. Menjawab Semua Pertanyaan tentang Nikah Siri. Yogyakarta: Pustaka Yustisia, 2010.

Mulati. Hukum Perkawinan Islam. Tangerang: PT Pustaka Mandiri, 2012. 
ND, Mukti Fajar. ND dan Yulianto Achmad. Dualisme Penelitian Hukum Normatif \& Empiris. Cetakan ke-1. Yogyakarta: Pustaka Pelajar, 2010.

Rafiq, Ahmad. Hukum Islam di Indonesia. Jakarta: PT.Raja Grafindo Persada, 1995.

Mahkamah Agung. Pedoman Teknis Administrasi dan Teknis Peradilan Agama. Jakarta: 2010.

\section{B. Peraturan Perundang-Undangan.}

Indonesia. Undang-Undang Dasar Negara Republik Indonesia Tahun 1945 . Undang-Undang Nomor Tahun 1974 Tentang Perkawinan . Instruksi Presiden Nomor 1 Tahun 1991 Tentang Kompilasi Hukum Islam . Peraturan Pemerintah Nomor 9 Tahun 1975 Tentang Pelaksanaan Undang-Undang Nomor 1 Tahun 1974 Tentang Perkawinan.

\section{Jurnal}

Aisyah Rasyid, "Problematika Anak Sah Dalam Prespektif Hukum Nasional Dan Putusan MK Nomor 46 Tahun 2010”, Vol II.

Muhammad Nur, "Kedudukan Harta Bersama Dalam Prespektif Hukum Islam”, Vol 1 No. 3, Tahun 2013.

Pemberdayaan Perempuan Kepala Keluarga (PEKKA), "Panduan Pengajuan Itsbat Nikah", (Laporan Penelitian--Jakarta, Australia Indonesia partnership, 2012). 
H.Suhandak, "Problematika Isbat Nikah Isteri Poligami Dalam Penyelesaian Pengadilan Agama", https://app.box.com/s/isp3x2azh1, 1 April 2018.

Drs. H. Masrum M Noor, MH., Penetapan Pengesahan Perkawinan (Itsbat Nikah) Bagi Warga Negara Indonesia Di Luar Negeri, http://pajakartapusat.go.id/weblama/images/PENETAPAN_PENGESAHAN _PERKAWINAN.pdf. 25 April 2018.

\section{Wawancara}

Peneliti. Wawancara, dengan Bapak Muhammad Abudan, selaku Dosen Fakultas Hukum Universitas Tarumanagara, (Jakarta, 8 Juni 2018).

. Wawancara, dengan Bapak Drs H. Djuwadi, selaku Hakim Ketua Pada Putusan Nomor 1478/Pdt.G/2016/PAJT, (Jakarta, 28 Juni 2018).

- Wawancara, dengan Ibu Mulati, selaku Dosen Fakultas Hukum Universitas Tarumanagara, (Jakarta, 17 Juli 2018).

- Wawancara, dengan Ibu DR Wahyuni Retno, S.H, M.H, selaku Dekan dan Dosen Universitas Trisakti, (Jakarta, 26 Juli 2018). 